\title{
The Influence of Social Media on Students' Academic Life in Higher Education: The Case of University for Development Studies, Tamale
}

\author{
Franklina Adjoa Yebowaah* Job Asante \\ University for Development Studies, Tamale, Ghana
}

\begin{abstract}
In recent times the proliferation of Information and Communication Technology has facilitated social interaction among different groups of people. Besides, communication in different forms is now easy with the creation of social media platforms that enable large groups of people to have a common discussion on a common platform. Some students of higher educational institutions are addicted to the use of these social media sites and could be detrimental to their academic achievement if not used effectively. This study provides empirical evidence from the Wa Campus students of the University for Development Studies (Ghana) on their awareness, use and effects of use of social media on their academic life. Primary data were collected from 380 randomly selected students through the use of a questionnaire and the data were analysed using descriptive statistics. With the exception of $2 \mathrm{go}$ and Tumblr where $46.1 \%$ and $44.7 \%$ of the respondents respectively are aware of, almost $80 \%$ of the respondents are aware of all the social media sites identified. The results therefore, indicate high awareness of current social media sites among the students with all the respondents becoming aware of at least Facebook and WhatsApp. Average time spent on frequently used social media sites is 40 hours per week. The use of smartphones, tablets and laptops which are very mobile is responsible for the relative higher intensity of social media use. The results also point out that social media sites are used for entertainment, social networking with friends and families, as well as for academic purpose. It is concluded that there are mixed effects of social media use on students' academic life. The University's Students Representative Council in collaboration with top management should develop strategies of informing students on the negative use of social media in their life.
\end{abstract}

Keywords: Social Media, Academic Life, Information Literacy, Tertiary Students

DOI: $10.7176 /$ RHSS/10-4-13

Publication date: February $29^{\text {th }} 2020$

\subsection{Introduction}

Social media has become an integral part of our daily lives, due to the impact it has on our social life. In recent years; use of social media has become very popular around the world due to the great development of technology (Amin et al., 2016). The issue of social media over the years has become a debatable topic among researchers with regard to its effect on academic performance. With the advent of information and communication technology, students have been significantly influenced in their social interaction (Desmal, 2017). This occurs with the aid of smartphone, laptop and tablets as some ICT gadgets that students use in accessing these social networking sites (Vigie \& Andnala, 2015). This means that the availability of ICT equipment is facilitating student access which can be used to their advantage.

However, social media sites can be used in socialization in ways that can defeat the academic objectives of student (Okundia, 2016). This implies that an ineffective use of social media in student life can have a negative effect on academic performance. The social network sites and social media have revolutionized the world bringing as closure than ever before; thus presenting various options for the student in terms of the purpose of use. Students are getting addicted to these sites day by day and the number of users is on the raise, this proves that e-world is taking its toll over the real world (Rithika \& Selvaraj, 2013). In effect, the usages of these sites benefits are abounded such as sharing information and ideas, improving reading skills among others (Mingle \& Adams, 2015).

\subsection{Problem statement}

Empirical studies such as Desmal (2017), Peiro-Velert et al. (2015) and Muhingi et al. (2015) maintain that there is use of social media among student following the advent of smartphones and internet connection. However, there have been mixed reactions from academics and researchers with regard to the impact of social networks and how they affect academic performance. For instance, Muhingi et al. (2015) study reported both positive and negative effects on student. Again, Junco (2011) explicitly maintained that sharing links and checking to see what friends are up to are positively related to GPA while posting status updates in negatively related to GPA. Some other studies such as Peiro-Velert et al. (2015) established that boys used more passive videogames and computer for playing than girls who tend to use mobile phones to communicate with others.

In support, Ellore et al. (2014) indicated that addiction to the internet and online social networks sites can affect a student's academic performance both positively and negatively. This conforms to Peter (2015) argument 
that student's addictiveness to social networks has a significant influence on their academic performance. Mingle (2016) stated that the ability of students not to discern and use social media properly could affect his or her studies and could result in lower grades. Othman et al. (2017) added that despite the many benefits of in our daily activates, it obviously can give negative effect impact if not used wisely. An investigation on the impact of online social networking on academic performance among senior high school students in Nariobi indicated that both parents and teachers felt that the Social Network Sites (SNS) negatively affects the academic performance of students while the students themselves felt that their performances was not directly affect by the SNS influence (Mwadime, 2015). Kiplagat and Ombiro (2017) stressed not only are parents and teachers releasing the effect of social media on academic performance but students and principals strongly agreed that access of social media site by high school students has affected negatively their academic language usage hence performance.

The forgoing discussing provides mixed findings on the influence of social media on students' performance. The Wa-Campus of the University for Development (UDS) contains greater proportion of students partly because of social science and business programmes that are being run. It has been observed that many students are now using smartphones with internet connectivity and hence participate in social media sites and programmes. it has been reported elsewhere by Ada and Anyebe (2017), Okundia (2016), and Ogundijo (2014) that students spend considerable time on social media. This act is worrisome since it has the potential effect of reducing the time available for studies. The empirical studies on the influence of social media and academic performance are conducted outside Ghana. Therefore, there is limited evidence on how UDS student use social media and its influence on their academic performance. It is therefore, uncertain whether social media and technologically assisted gargets such as smartphones will aid in improving academic excellence among the student.

\subsection{Objectives of the study}

The study sought to achieve the following objectives

1. To analyse students' awareness of social media sites

2. To analyse students use of social media sites

3. To examine the effect of use of social on student academic life

\subsection{Literature Review}

\subsection{Social Media Sites}

In assessing the impact of social media on students' academic performance, a lot of scholars have identified several search engines that students use in their social media activities. For instance, Amin et al. (2016) established that the social media sites that capture the attention of students include Facebook, twitter, Google+ and Skype. Vigie and Andnala (2015) revealed that search engines such as Facebook, instagram, Tumblr, Google and yahoo are the social networking sites that students are using. Similarly, Ada and Anyebe (2017) discovered that students of Federal College of education of Nigeria use several media such as Facebook, Twitter, Whatsapp, 2go and instagram to engage in their activities. Comparatively, students are very fond of using Facebook, twitter, YouTube and orkut in their media activities (Rithika \& Selvaraj, 2013). A similar finding was found in Kenyan where Kiplagat and Ombiro (2017) noted that students access the internet and social media sites and the frequented sites were Facebook, Whatsapp, twitter, Instagram and YouTube.

The most popular social media sites often used by students have been identified by empirical studies to include Whatsapp and Facebook (Desmal, 2017; Mingle, 2016; Mingle \& Adams 2015; Kashif, 2013; Alwagait et al., 2014; Othman et al., 2017). Other studies such as Alwagait et al. (2014) also observed twitter is also emerging as a dominant social media site used by students. Factors that make these social networks dominant over the others have been identified by Kashif (2013) to include charges (cheap), fastness and entertaining medium of communication. Another, most common reason why students use social media in the order of their popularity is to share knowledge and information with others, to stay in close touch with family and maintain valued relationship with other people and for entertainment purposes (Okundia, 2016). The reasons suggested imply that students often use social media for reasons not related to academic activities.

\subsubsection{Time spent on social media}

Several empirical studies report on the frequency and usage of social networking sites among students. For example, Ada and Anyebe (2017) report that students in federal college of education in Nigeria waste too much time talking on social network at the expense of their studies. In their view, the rate at which students spend time on social network is worrisome and may pose imminent danger to society. Okundia (2016) study in Nigeria revealed that majority of students visit at a least one social media sites several times daily. Specifically, Ogundijo (2014) estimates that students access the internet between 1-5 hours per week, however with purposes of retaining courses related information. In Kenyan, Kiplagat and Ombiro (2017) found that secondary school spends an average of over 2 hours per day in accessing social media sites. Besides, Peiro-Velert et al. (2015) revealed that some students spent 5.5 to 8 hours daily on social media sites. 


\subsection{Reasons for using Social Media}

It has been found that students use social media for several reasons. According to Okundia (2016), the main reason often cited by students include: sharing knowledge and information with others, staying in close touch with family, maintain valued relationship with other people, and for entrainment purposes (Okundia, 2016). In the report of Vigie and Andnala (2015), students use social media to engage in social interaction and information gathering.

Several studies are arriving on the same conclusion that students often use social media for entertainment purpose. A review of these studies identify Mingle and Adams (2015) in Ghana, Othman et al. (2017) in Malaysia, Kiplagats and Ombiro (2017) and Mwadime (2015) both in Kenya. Further evidence provided by Kiplagats and Ombiro (2017) are that student use social media sites to watch pornographic materials. This habit can weaken the moral standard of the students and divert their attention from purely academic exercise. These facts suggest that even if students use social media site for academic purpose, yet their time for studies will in one way be lots and hence their academic performance affected negatively.

On the other hand, Mingle and Adams (2015) reported that student have been using social media sites to gather academic information. This means that social media can help them to improve their information literacy skills by discovering online resources with convenience. Besides, as they chart with one another and sharing messages and videos, they may engage in dissemination of relevant academic information such as lecture notes (Mwadime, 2015).

\subsection{Effects of social media on students' performance \\ 2.3.1 Positive Impact of Social Media on Students' Performance}

Also, Amin et al. (2016) revealed that because of the time spent on these social media sites, students are able to share and generate new ideas and concept related to relate to their studies. Confirming this, Mingle and Adams (2015) claim that they are a lot benefits associated with social media such as sharing information and ideas, improving reading skills among others. In the same way, Othman et al. (2017) indicated that students archive a lot by using the social media in discussing ideas and sharing information hence increases students' performance. According to them, students also use these sites for having fun as these social websites are helpful in their academic work. Faculties and students are now pushing learning beyond the borders of classroom through social networking (Rithika \& Selvaraj, 2013). Desmal (2017) study established that use of social media have significant effect on education, as it not only increased students research ability but also increased students group discussion skills. To him, social media enable students to engage in academic activities beyond the traditional classroom, because the social media can be used at anytime and anywhere by teachers and students for variety of academic purposes. Peter (2015) revealed that the use of social media has significant influence on academic performance of students in University of Lagos. Equally, the effect of social media can be positive as in the study of Mingle (2016) who closely determine the real effect of social media sites which includes improvement in reading skills and writing.

However, it is clear that the ability of students not to discern and use it properly could affect his or her studies and could result in lower grades. Aside it positive impact on student's academic performance, further results found that social media especially Facebook brings, bond and maintain relationship though it is very effective for making new relationship (Kashif, 2013). In Malaysian the use of social media provides collaborate learning and engagement that are useful for postgraduate students and researchers (Al-Rahmi et al., 2015). They concluded that the use of social media in research groups would enable the researchers to accomplish task more quickly and using social media enhances research effectively.

\subsubsection{Negative Impact of Social Media on Students' Performance}

Conversely, a number of researchers and studies have found that negative impact of social network outweigh the positive effect on students' academic performance. In Ghana, Mingle and Adams (2015) experience negative effect such as poor grammar and spelling, late submission of assignment, less study time and poor academic performance among Senior High School students due to their heavy participation on social media networks. In Kenyan also, it is revealed that as a result of the use of social media, students use short form of words when writing notes, answering question in class and when they are having their conservation (Kiplagat \& Ombiro, 2017). In Nigeria, Peter (2015) point out that social media have a negative effect on teenagers such as lack of privacy, distraction students from their academic work, taking most of their productive time. Junco (2011) work on "Too much face and not enough books" concluded that more use of social media sites does not improve academic performance. That is to say that despite the benefit that comes with participation of students on social media networks, it could impact negatively on their academic performance if not used properly.

In the study of Muhingi et al. (2015), secondary school students in Kenya were much more vulnerable to the adverse effect of social networks in a manner consistently and concurrently similar to that found elsewhere in the worldwide. Their study produce strong evidence that low GPA scored were found out to be directly related to long hours usage of Facebook. A higher proportion of respondents from private schools experiences drop in grades as compared to the students in the public schools because they spent more time online (Mingle, 2016). Krischne and Karpinski (2009) study on Facebook and academic performance shows that Facebook users and nonusers were 
significantly different from each other with Facebook users reporting both lower mean GPA and spending fewer hours per week studying. Similar results on the negative effects on social media use on academic performance were reported by Alwagait et al. (2014) in Saudi Arabia, Othman et al. (2017) in Terengganu of Malaysia, Okundia (2016) in Benin, and Kiplagat and Ombiro (2017) in Kenya. Due to the repercussion that social media might have on the academic performance of students, cell phones have been banned from classroom and schools have blocked many popular social media website (Okundia, 2016). Restriction of student from participating in social media can be a good management decision when it is clear that use of these sites by students does not really improve their academic performance. However, management can become uncertain in their decision where a mixed effect of social media use has been recorded or when there is no available evidence at all such as the case of UDS.

\subsubsection{Mixed effects of social media use on students' academic performance}

Peter (2015) study revealed that boys have been using social media more than girls in previous decades because of early forms of technology such as video or computer games ad this can brings variations in their academic performance. Peiro-Velert et al. (2015) results clearly made this point clear. Their study on screen media usage, sleep time and academic performance in adolescents revealed that boys who spent more than 5.5 hours daily on sedentary screen media slept an average of 8 hours daily and hence recorded low academic performance. On the other hand they gathered that girls with excellent academic performance sleep early 9 hours per day and devoted less time to sedentary screen media. This implies that the amount of time spend on social media reduces the time available for sleep and hence has an inverse relationship with students' academic performance. A comparative analysis of social media usage and academic performance in public and private senior high schools shows that students from the private school spent more time online as compared to counterpart in the public school (Mingle, 2016). Mingle (2016) therefore, concludes that time spent on social media has a negative influence on academic performance. Muhingi et al. (2015) added that most students spent more of their time on recreational social network at the expense of pursuance for academic excellence, thereby lowering their academic standard in secondary school in Kenyan.

Some available evidence suggests that academic performance of students is independent on time spent on social media. Results from Pasek et al. (2009) show that the two variables are unrelated, thus changes in academic achievement did not vary with Facebook use when demographic controls were considered. Akanbi and Theophilus (2014) findings on the influence of social media usage on self-image and academic performance show that there is no correlation between social media usage and academic performance. Consistent with this observation, Ellore et al. (2014) indicated that the amount of time spent on these social networks (Facebook) does not have a significant relationship with either academic performance. Identically, Ogundijo (2014), study shows that time spent on SNSs did not significantly influences academic performance of secondary school students. These arguments contradict the foregoing discussing on the influence of social media on academic performance. This will make management of academic institutions uncertain regarding the regulation of use of social media on campus. The situation will even be more complex in areas such as UDS (Ghana) where related studies are limited and management lack evidence on the influence of the use of social media on their students' academic life.

\subsection{Methodology}

This section presents the general procedures used to carry out the study. It specifically presents the research design, study population, sampling procedure, data requirements and sources, and the methods of data analysis respectively.

Research Design: A research design describes the general research strategy (Creswell, 2014; Kumar, 2011). It comprises of the various steps that are adopted in studying the problem. Thus, the function of a research design is to ensure that requisite data in accordance with the problem at hand is collected accurately and economically (Kothari, 2004). This is a descriptive research design. According to Kothari (2004), a descriptive study portrays accurately the characteristics of a particular individual, situation or a group. "Such studies look at individuals, groups, institutions, methods and materials in order to describe, compare, contrast, classify, analyse and interpret the entities and the events that constitute their various fields of inquiry" (Cohen et al., 2007: 205). This study therefore, describe students of the University for Development Studies, Wa Campus in terms of their awareness and use of social media sites, as well as the influence of social media in their academic life.

Population and Sampling: The population of the study consists of students of the University for Development Studies, Wa Campus that are currently enrolled in various undergraduate programmes during the 2017/18 academic year. The current population of students of the Wa Campus is 7,409. This consists of 2,098 students from the Faculty of Integrated Development Studies (FIDS), 1,811 students from the Faculty of Planning and Land Management (FPLM), and 3500 students from the School of Business and Law (SBL).

The sample size was estimated using statistical procedure proposed by Yamane (1967). The formula is given as:

$$
\mathrm{n}=\frac{\boldsymbol{N}}{1+N(e)^{2}}
$$

Where $\mathrm{n}=$ sample size; $\mathrm{N}=$ sample frame and $\mathrm{e}=$ error or significance level. According to Ahuja (2001), an 
acceptable error level traditionally is up to \pm 0.05 or \pm 0.10 (i.e., 5 or 10 percentage point). In this study, $\mathrm{N}=7409$, $\mathrm{e}=5 \%$. Hence the estimated sample size for the study is

$$
\mathbf{n}=\frac{7409}{1+7409(0.1)^{2}}=380
$$

The sampling distribution according to faculties is shown in the Table 1 below.

Table 1: Sampling Distribution of Respondents.

\begin{tabular}{lcc}
\hline Faculty & Population of students & Sample size \\
\hline FIDS & 2098 & 108 \\
FPLM & 1811 & 93 \\
SBL & 3500 & 179 \\
\hline Total & $\mathbf{7 4 0 9}$ & $\mathbf{3 8 0}$ \\
\hline
\end{tabular}

Source: Author's Construct (2018)

Stratified sampling technique was used to select the 380 students from the three faculties of the Wa Campus of the University for Development Studies. The sample size was distributed proportionally to the number of undergraduate students per faculty as shown in Table 1.

Data Collection and Analysis: The data were collected using a questionnaire. The main sections of the questionnaire include the background information of the respondents, awareness of social media sites, use of social media sites, extent of use and time spent on social media sites. Other sections of the questionnaire address issues on the influence of social media on students' academic life. The questionnaires were given to the respondents to self-administer once the population under study is literate. Copies of the questionnaire were distributed to the respondents and all of them were retrieved. The data were cleaned and coded into the SPSS spread sheet for analysis. The results were analysed using descriptive statistics and presented using cross tabulations.

\subsection{Results and Discussion}

4.1 Background Information of Respondents

It was discovered from the study that male students dominate (74.2\%) over the female students (25\%) as shown in Table 2. This means that males have a relative higher access to higher education than females. Besides, different ages were recorded with the minimum age of 18 years and a maximum of 33 years. The mean age of the respondents is 23.2 with a standard deviation of 3.06 .

Table 2. Background Information of Respondents

\begin{tabular}{lcccc}
\hline Gender & Frequency & Percent \\
\hline Male & 282 & 74.2 \\
Female & 98 & 25.8 \\
\hline Total & $\mathbf{3 8 0}$ & $\mathbf{1 0 0}$ \\
\hline Total & $\mathbf{3 8 0}$ & Maximum & Mean & Std. Deviation \\
\hline Variable & Minimum & 33 & 23.20 & 3.069 \\
\hline Age & 380 & 18 & &
\end{tabular}

Source: Field Survey (2018)

The higher representation of male students suggests that they dominate in the university and are more likely to be affected through the use of social media than their female counterparts. The age distribution suggests that all the students are within their youthfully age and are therefore, expected to facilitate their social interactions through the use of social media. The fact that they are students also means that social media can aid their learning activities.

\subsection{Awareness and use of Social Media Sites}

All the respondents have unanimously agreed that they are aware of social media and are in one way or the other engage in it use. Table 3 shows the distribution of responses on awareness and use of social media. From the table, the social media sites identified include facebook, WhatsApp, Yahoo, gmail, Twiter, Instagram, Skype, YouTube, Tumblr and 2 go. 
Table 3. Awareness and use of Social networking sites

\begin{tabular}{lccc}
\hline Social media & Aware & Ever used & Still use \\
\hline Facebook & $374(98.4 \%)$ & $339(89.2 \%)$ & $339(89.2 \%)$ \\
WhatsApp & $377(99.2 \%)$ & $357(93.9 \%)$ & $336(88.4 \%)$ \\
Yahoo & $332(87.4 \%)$ & $228(60.0 \%)$ & $108(28.4 \%)$ \\
Gmail & $356(93.7 \%)$ & $310(81.6 \%)$ & $310(81.6 \%)$ \\
Twitter & $303(79.7 \%)$ & $201(52.9 \%)$ & $106(27.9 \%)$ \\
Instagram & $309(81.3 \%)$ & $205(53.9 \%)$ & $174(45.8 \%)$ \\
Skype & $305(80.3 \%)$ & $140(36.8 \%)$ & $70(18.4 \%)$ \\
YouTube & $343(90.3 \%)$ & $283(74.5 \%)$ & $275(72.4 \%)$ \\
Tumblr & $175(46.1 \%)$ & $45(11.8 \%)$ & $23(6.1 \%)$ \\
2go & $170(44.7 \%)$ & $49(12.9 \%)$ & $11(2.9 \%)$ \\
\hline
\end{tabular}

Source: Field Survey (2018) multiple responses were considered

With the exception of $2 \mathrm{go}$ and Tumblr where $46.1 \%$ and $44.7 \%$ of the respondents are aware of, almost $80 \%$ of the respondents are aware of all the social media sites identified and presented in Table 3 . In terms of used, the proportion of students who ever used these sites are lower than their awareness levels. This means that students are aware of some social media sites that they have never used. However, sites with high patronage (in order of importance) among the students include: WhatsApp (93.9\%), Facebook (89.2\%), gmail (81.6\&), YouTube (74.5\%). Besides, the proportion of students who have ever used Yahoo, Twitter, and Instagram ranges between $50-60 \%$ while the proportion which has ever used Skype, Tumblr and 2 go is less than $40 \%$. The proportion of students who are still using these sites further reduced and this means that some have stopped using some social media platforms. For example in Table 3, the percentage of students using Facebook, WhatsApp, and gmail are still above $80 \%$, those using YouTube stand at $72.4 \%$ while less than $50 \%$ in either case use the other sites shown in the table. Consistent with empirical studies, this has found Facebook and WhasApp as the most frequently used social media sites among students of UDS. These popular sites grant users the opportunity to share multi-media images among friends.

The intensity of use; measured by how frequent one use social media sites and the amount of time spent on the site was analysed. First, the frequency of use was measured by a three point likert scale consisting of those who use it very frequent, occasional use, and not using it at all. The responses in terms of frequencies and percentages are shown in Table 4. WhatsApp recorded higher frequency of use because $99.2 \%$ of the respondents use it very frequently and only $0.8 \%$ not using it at all. Besides, $78.7 \%$ use Facebook very frequent, $19.7 \%$ use it occasional and 1.6\% not using Facebook at all. A part from gmail which recorded $45.5 \%$ very frequently used all the other sites as identified in the study recorded low intensity of use.

\begin{tabular}{lccc}
\multicolumn{4}{l}{ Table 4. Extent to which you use the following media sites } \\
\hline \multicolumn{1}{l}{ Social Media } & Very frequent & Occasional & Not at all \\
\hline Facebook & $299(78.7 \%)$ & $75(19.7 \%)$ & $6(1.6 \%)$ \\
WhatsApp & $377(99.2 \%)$ & $0(0.0 \%)$ & $3(0.8 \%)$ \\
Yahoo & $51(13.4 \%)$ & $159(41.8 \%)$ & $170(44.7 \%)$ \\
Gmail & $173(45.5 \%)$ & $183(48.2 \%)$ & $24(6.3 \%)$ \\
Twitter & $81(21.3 \%)$ & $79(20.8 \%)$ & $220(57.9 \%)$ \\
Instagram & $98(25.8 \%)$ & $108(28.4 \%)$ & $174(45.8 \%)$ \\
Skype & $34(8.9 \%)$ & $89(23.4 \%)$ & $257(67.6 \%)$ \\
YouTube & $174(45.8 \%)$ & $129(33.9 \%)$ & $77(20.3 \%)$ \\
Tumblr & $29(7.6 \%)$ & $14(3.7 \%)$ & $337(88.7 \%)$ \\
2go & $16(4.2 \%)$ & $24(6.3 \%)$ & $340(89.5 \%)$ \\
\hline
\end{tabular}

Source: Field Survey (2018)

multiple responses were considered

It is possible that students may not use some social media sites frequently but allocate considerable time for it when they are using it. From Table 5, WhatsApp and Facebook still recorded highest average time spent on them and this is about 40 hours per week. This time frame is equivalent to the average time a public sector employee work in Ghana within a week. Instagram and YouTube also recorded 35.83 and 36.2 hours per week respectively. This means that students do not often use Instagram but when they do, they spent considerable time on it. On the other hand, the average time spent on Yahoo (13.83 hours), Twitter (16.27 hours) and Skype (15.63) recorded almost the same time allocated for it use. it appears that the time spent on social media sites among students of UDS is relative higher than the reports of past studies. For example, Ogundijo (2014) report 1-5 hours of time spent on social media per week while Peiro-Velert et al. (2015) report 5.5 to 8 hours per day. 
Table 5. Time (Number of Hours) spent per week

\begin{tabular}{lccccc}
\hline Variable & $\mathbf{N}$ & Minimum & Maximum & Mean & Std. Deviation \\
\hline Facebook & 359 & 10 & 57 & 40.17 & 6.18 \\
WhatsApp & 370 & 15 & 60 & 40.83 & 3.23 \\
Yahoo & 167 & 1 & 30 & 13.83 & 4.78 \\
Gmail & 271 & 2 & 15 & 7.50 & 6.73 \\
Twitter & 116 & 10 & 22 & 16.27 & 6.02 \\
Instagram & 138 & 5 & 60 & 35.83 & 8.10 \\
Skype & 82 & 0 & 28 & 15.63 & 4.28 \\
YouTube & 244 & 15 & 57 & 36.20 & 1.00 \\
Tumblr & 32 & 0 & 14 & 7.20 & 7.01 \\
2go & 28 & 0 & 5 & 2.83 & 2.57 \\
\hline
\end{tabular}

Source: Field Survey (2018)

Student use different ICT gargets to access social media sites. These gargets with their proportion of use as shown in Table 6 are Smartphones (94.4\%), Laptop computers (19.2\%), Tablets (9.2\%) and Desktop computers $(0.8 \%)$.

Table 6: Devices use in accessing social media sites

\begin{tabular}{lcc}
\hline Device & Frequency & Percent \\
\hline Smartphone & 355 & 93.4 \\
Laptop computer & 73 & 19.2 \\
Tablet & 35 & 9.2 \\
Desktop computer & 3 & 0.8 \\
\hline
\end{tabular}

Source: Field Survey (2018) multiple responses were considered

Majority of the students are using Smartphones and these are very mobile and can be used to access social media sites all the time. This will facilitate effective and misuse of social media sites on students' academic life. On the other hand gargets such as Desktop and Laptop computers are not very convenient to carry everywhere when they are not specifically needed. For example, such gargets can be easily carried to the lecture room and being in used as lectures goes on and hence their use will not easily affect academic life of students.

It was discovered from this study that students do different things with social media sites. Prominent among them as shown in Table 7 include: sharing of social information including pictures and videos, charting with friends and families, and sharing of academic information.

Table 7: Students' Social Media Activities

\begin{tabular}{lccc}
\hline Social media & $\begin{array}{c}\text { Sharing social } \\
\text { information }\end{array}$ & Chatting & $\begin{array}{c}\text { Sharing academic } \\
\text { information }\end{array}$ \\
\hline Facebook & $242(63.7 \%)$ & $214(56.3 \%)$ & $134(35.3 \%)$ \\
WhatsApp & $220(57.9 \%)$ & $328(86.3 \%)$ & $277(72.9 \%)$ \\
Yahoo & $87(22.9 \%)$ & $40(10.5 \%)$ & $107(28.2 \%)$ \\
Gmail & $142(37.4 \%)$ & $82(21.6 \%)$ & $214(56.3 \%)$ \\
Twitter & $79(20.8 \%)$ & $64(16.8 \%)$ & $40(10.5 \%)$ \\
Instagram & $92(24.2 \%)$ & $54(14.2 \%)$ & $39(10.3 \%)$ \\
Skype & $45(11.8 \%)$ & $69(18.2 \%)$ & $30(7.9 \%)$ \\
YouTube & $81(21.3 \%)$ & $21(5.5 \%)$ & $74(19.5 \%)$ \\
Tumblr & $34(8.9 \%)$ & $22(5.8 \%)$ & $23(6.1 \%)$ \\
2go & $29(7.6 \%)$ & $23(6.1 \%)$ & $23(6.1 \%)$ \\
\hline
\end{tabular}

Source: Field Survey (2018) multiple responses were considered

The results of this study are consistent with past studies on the reasons for using social media sites. For example, Okundia (2016) report that social media sites are used for sharing knowledge with others, staying in close touch with family, and for entertainment purpose have been confirmed by this study. This suggests that there is a universal purpose of social media use across the globe. In this study, evidence of use of social media for pornography has not been confirmed unlike the observation made by Kiplagats and Ombiro (2017) in Kenya. However, the moral implication of this act could lower the confidence of respondents to point it out that they have been watching pornography as students. Once there is no legal restriction of the use of to watch pornographic images students may have the tendency to visit pornographic sites or share nude images through social media. Finally, there is a consensus between past studies and the findings of this study on the use of social media for academic activities. Hence the results of Mingle and Adams (2015) elsewhere in Ghana has been confirmed in this study when students were found using social media in sharing academic information.

From Table 7, all the widely used social media sites as well as those on which much time has been spent on are usually used either in sharing social information or chatting with friends and families. However, despite the widely used of WhatsApp for social activities, $72.9 \%$ of the students still use it for academic purposes. Other 
platforms widely used for academic purpose include gmail with a relative higher proportion $(56.3 \%)$ of the respondents using it for sharing academic information. This means that students' social media activities are more of entertainment and communication with friends and families than for academic use. These results imply that the large number of hours that are being spent on social media sites are not for academic purposes and hence will invariably reduce the average time available for studies.

\subsection{Effects of Social Media on Students' Life}

The study identified both positive and negative effects of social media use on students' academic life. First, Table 8 shows the distribution of respondents' level of agreement on the positive effects of social media on their academic life. The responses were based on analysis of a five-point likert scale of Strongly Disagree (SD), Disagree (D), Neutal (N), Agree (A) and Strongly Disagree (SD). From the table, variables with strong agreements by at least $40 \%$ of the respondents include: being able to search and identify relevant academic information (45.5\%), sharing with friends some relevant academic information $(51.3 \%)$, social media improving reading and communication skills (44.7\%), and the ability of social media to extend learning beyond the classroom. This means that majority of the respondents have at least agreed on the under listed potentials of social media on students' academic life.

Table 8: Positive Effects of Social Media on Student Academic Life

\begin{tabular}{|c|c|c|c|c|c|}
\hline Positive effects of social media & SD & D & $\mathbf{N}$ & $\mathbf{A}$ & SA \\
\hline I am now very conversant with ICT & $\begin{array}{c}13 \\
(3.4 \%)\end{array}$ & $\begin{array}{c}52 \\
(13.7 \%)\end{array}$ & $\begin{array}{c}52 \\
(13.7 \%)\end{array}$ & $\begin{array}{c}161 \\
(42.4 \%)\end{array}$ & $\begin{array}{c}102 \\
(26.8 \%)\end{array}$ \\
\hline $\begin{array}{l}\text { I can now search and identify relevant academic } \\
\text { information }\end{array}$ & $\begin{array}{c}5 \\
(1.3 \%)\end{array}$ & $\begin{array}{c}16 \\
(4.2 \%)\end{array}$ & $\begin{array}{c}25 \\
(6.6 \%)\end{array}$ & $\begin{array}{c}161 \\
(42.4 \%)\end{array}$ & $\begin{array}{c}173 \\
(45.5 \%)\end{array}$ \\
\hline $\begin{array}{l}\text { Friends share with me relevant academic } \\
\text { information }\end{array}$ & $\begin{array}{c}14 \\
(3.7 \%)\end{array}$ & $\begin{array}{c}16 \\
(4.2 \%)\end{array}$ & $\begin{array}{c}44 \\
(11.6 \%)\end{array}$ & $\begin{array}{c}111 \\
(29.2 \%)\end{array}$ & $\begin{array}{c}195 \\
(51.3 \%)\end{array}$ \\
\hline $\begin{array}{l}\text { Social media improves my reading and } \\
\text { communication skills }\end{array}$ & $\begin{array}{c}12 \\
(3.2 \%)\end{array}$ & $\begin{array}{c}27 \\
(7.1 \%)\end{array}$ & $\begin{array}{c}43 \\
(11.3 \%)\end{array}$ & $\begin{array}{c}128 \\
(33.7 \%)\end{array}$ & $\begin{array}{c}170 \\
(44.7 \%)\end{array}$ \\
\hline Improves group discussion skills & $\begin{array}{c}10 \\
(2.6 \%)\end{array}$ & $\begin{array}{c}24 \\
(6.3 \%)\end{array}$ & $\begin{array}{c}64 \\
(16.8 \%)\end{array}$ & $\begin{array}{c}181 \\
(47.6 \%)\end{array}$ & $\begin{array}{c}101 \\
(26.6 \%)\end{array}$ \\
\hline $\begin{array}{l}\text { Strengthens students relationship and improves } \\
\text { social life }\end{array}$ & $\begin{array}{c}18 \\
(4.7 \%)\end{array}$ & $\begin{array}{c}24 \\
(6.3 \%)\end{array}$ & $\begin{array}{c}27 \\
(7.1 \%)\end{array}$ & $\begin{array}{c}193 \\
(50.8 \%)\end{array}$ & $\begin{array}{c}118 \\
(31.1 \%)\end{array}$ \\
\hline Increase my average score in school & $\begin{array}{c}64 \\
(16.8 \%)\end{array}$ & $\begin{array}{c}87 \\
(22.9 \%)\end{array}$ & $\begin{array}{c}97 \\
(25.5 \%)\end{array}$ & $\begin{array}{c}119 \\
(31.3 \%)\end{array}$ & $\begin{array}{c}13 \\
(3.4 \%)\end{array}$ \\
\hline Extents learning beyond the walls of classrooms & $\begin{array}{c}21 \\
(5.5 \%) \\
\end{array}$ & $\begin{array}{c}33 \\
(8.7 \%) \\
\end{array}$ & $\begin{array}{c}34 \\
(8.9 \%) \\
\end{array}$ & $\begin{array}{c}140 \\
(36.8 \%) \\
\end{array}$ & $\begin{array}{c}152 \\
(40.0 \%) \\
\end{array}$ \\
\hline $\begin{array}{l}\text { Improves distance learning, especially during } \\
\text { holidays }\end{array}$ & $\begin{array}{c}21 \\
(5.5 \%)\end{array}$ & $\begin{array}{c}27 \\
(7.1 \%)\end{array}$ & $\begin{array}{c}70 \\
(18.4 \%) \\
\end{array}$ & $\begin{array}{c}141 \\
(37.1 \%) \\
\end{array}$ & $\begin{array}{c}121 \\
(31.8 \%) \\
\end{array}$ \\
\hline Reduces expenditure on books & $\begin{array}{c}29 \\
(7.6 \%)\end{array}$ & $\begin{array}{c}34 \\
(8.9 \%)\end{array}$ & $\begin{array}{c}56 \\
(14.7 \%)\end{array}$ & $\begin{array}{c}113 \\
(29.7 \%)\end{array}$ & $\begin{array}{c}148 \\
(38.9 \%)\end{array}$ \\
\hline
\end{tabular}

Source: Field Survey (2018)

multiple responses were considered

The results also suggests that some variables depicting positive influence of social medial on students' academic life have been assessed to be week by the respondents. This is because the proportion of respondents with strong disagreement, disagreement or maintained a neutral position constitutes significant percentage of the respondent. The variable with such weak agreement is participation in social media leading to increase in average score in school. The results of this study have confirmed that of Mingle and Adams (2015), Othman et al. (2017), Rithika and Selvaraj (2013), and Desmal (2017) on the positive effects of social media on student academic life. This has been evidenced when found that students are using some sites especially, Yahoo, gmail, YouTube, Facebook and WhatsApp for sharing academic information. Another silent example as found in this study is when students were observed to have been using social media in learning outside the classroom, being able to search for relevant academic information and getting their readings skills improved. This means that social media improves the information literacy skills of students.

From Table 9, relatively large proportion of the respondents has at least agreed with the following negative influence of social media on their academic life. The negative influence includes: poor grammar and writing skills by using short-form of words, introducing students to pornography, compelling students to acquire mobile phones at the expense of books, and changing attention from academic life to social activities. More than $50 \%$ of the respondents have at least agreed (agree and or strongly agree) on these negative effects of social media on their academic life. 
Table 9: Negative Effects of Social Media on Student Academic Life

\begin{tabular}{lccccc}
$\begin{array}{l}\text { Negative effects of social media on } \\
\text { your life }\end{array}$ & SD & $\mathbf{D}$ & $\mathbf{N}$ & $\mathbf{A}$ & SA \\
\hline $\begin{array}{l}\text { Poor grammar and writing skills by } \\
\text { using short-form of words }\end{array}$ & $61(16.1 \%)$ & $42(11.1 \%)$ & $41(10.8 \%)$ & $108(28.4 \%)$ & $128(33.7 \%)$ \\
\hline Late submission of assignment & $85(22.4 \%)$ & $152(40.0 \%)$ & $64(16.8 \%)$ & $70(18.4 \%)$ & $9(2.4 \%)$ \\
\hline Less time available for study & $37(9.7 \%)$ & $50(13.2 \%)$ & $117(30.8 \%)$ & $111(29.2 \%)$ & $65(17.1 \%)$ \\
\hline Poor academic performance & $89(23.4 \%)$ & $84(22.1 \%)$ & $89(23.4 \%)$ & $87(22.9 \%)$ & $31(8.2 \%)$ \\
\hline Introduce to pornographic & $27(7.1 \%)$ & $27(7.1 \%)$ & $54(14.2 \%)$ & $155(40.8 \%)$ & $117(30.8 \%)$ \\
\hline Lack of privacy & $45(11.8 \%)$ & $80(21.1 \%)$ & $119(31.3 \%)$ & $95(25.0 \%)$ & $41(10.8 \%)$ \\
\hline Increase sexuality & $38(10.0 \%)$ & $52(13.7 \%)$ & $89(23.4 \%)$ & $135(35.5 \%)$ & $66(17.4 \%)$ \\
\hline $\begin{array}{l}\text { Compels students to acquire mobile } \\
\text { phones }\end{array}$ & $31(8.2 \%)$ & $23(6.1 \%)$ & $26(6.8 \%)$ & $194(51.1 \%)$ & $106(27.9 \%)$ \\
\hline $\begin{array}{l}\text { Students pay attention to social media } \\
\text { than acad }\end{array}$ & $14(3.7 \%)$ & $34(8.9 \%)$ & $67(17.6 \%)$ & $177(46.6 \%)$ & $88(23.2 \%)$ \\
\hline
\end{tabular}

than academic work

Source: Field Survey (2018)

multiple responses were considered

The observation made by Mingle and Adams (2015) that student often submit their assignment late resulting from social media use has not been confirmed by this study. However, other observations regarding less time for studies, short hand style of writing, wasting of productive times as argue by Mingle and Adams (2015), Kiplagat and Ombiro (2017) and Peter (2015) has been confirmed by the results of this study.

\subsection{Conclusion and Recommendation}

Social media has now become part and parcel of student life following technological revolution especially an improvement in knowledge of ICT. Students have therefore, become aware of most of the emerging social media sites and how to use them. However, most frequently used social media sites have been the Facebook and WhastApp in different places all over the globe. There has been consensus on the effect of purpose and effects of social media sites among students. This means that the effect of social media use on academic performance is assuming similar trend as has been confirmed by different studies. Among students of UDS, social media has mixed effects on student academic life and this implies that effective utilization of social media very much depend on the objective of the student. Gargets use to access social media sites are mostly smartphones, laptops and tablets which are very mobile. This means that Universities management will have challenges in controlling the negative use of social media since students can visit these sites in private and wherever they found themselves.

It therefore, recommended that ways of improving students' academic performance should include strategies of minimizing the negative use of social media sites among students. Besides, effective sensitization of the negative effects of social media be carried out in the University for Development Studies Campus to draw students attention on the dangers of social medial misappropriation. This development can be initiated by the Student Representative Council with support from management.

\section{References}

Ada, A. and Anyebe, A. A. (2017). Study habit and academic performance of Christian Religious Studies students in Federal College of Education, Zaria, Nigeria. Integrity Journal of Education and Training. Vol. 1. Page 34-40. Article Number: IJET-14.07.17-012, Creative Commons Attribution License 4.0. www.integrityresjournals.org/ijet/index.html.

Akanbi, M. I. and Theophilus, A. B. (2014). Influence of Social Media Usage on Self-Image and Academic Performance among Senior Secondary School Students in Ilorinwest Local Goverment, Kwara State. International Research Journal of Pure and Applied Physics. Vol.2, No.4, pp.42-50. Published by European Centre for Research Training and Development UK (www.eajournals.org) ISSN 2055-009X(Print), ISSN 2055-0103(Online).

Al-Rahmi, W. M., Othman, M. S. and Yusuf, L. M. (2015). The Role of Social Media for Collaborative Learning to Improve Academic Performance of Students and Researchers in Malaysian Higher Education. Creative Commons Attribution 4.0 International License. International Review of Research in Open and Distributed Learning. Vol. 16(4).

Alwagait, E., et al. (2014). Impact of social media usage on students' academic performance in Saudi Arabia. Computers in Human Behavior, http://dx.doi.org/10.1016/j.chb.2014.09.028. www.elsevier.com/locate/comphumbeh.

Amin, Z., Mansoor, A., Hussain S. R. and Hashmat, F. (2016). Impact of Social Media of Student's Academic Performance. International Journal of Business and Management Invention, Vol. 5(4), ISSN (Online): 2319 - 8028, ISSN (Print): 2319 - 801X. PP-22-29, www.ijbmi.org. 
Desmal, A. J. M. (2017). The impact of using social media and internet on academic performance: case study Bahrain Universities. EAI Endorsed Transactions on Scalable Information Systems. Vol. 4(13) Creative Commons Attribution licence http://creativecommons.org/licenses/by/3.0/. doi: 10.4108/eai.28-62017.152748

Ellore, S. B., Niranjan, S. and Brown, U. J. (2014). The Influence of Internet Usage on Academic Performance and Face-to-Face Communication. Journal of Psychology and Behavioral Science. Vol. 2(2), pp. 163-186, ISSN: 2374-2380 (Print) 2374-2399 (Online). American Research Institute for Policy Development.

Jato, M., Ogunniyi, S. O. and Olubiyo. P. O. (2014). Study habits, use of school libraries and students' academic performance in selected secondary schools in Ondo West Local Government Area of Ondo State. International Journal of Library and Information Science. Vol. 6(4), pp. 57-64, DOI: 10.5897/IJLIS2012.0412, Article Number: 10E5AEA47583, ISSN 2141-2626. http://www.academicjournals.org/IJLIS.

Junco, R. (2011). Too much face and not enough books: The relationship between multiple indices of Facebook use and academic performance. Computers in Human Behavior. doi:10.1016/j.chb.2011.08.026.

Kashif, M. (2013). Impact Of Facebook On Students' Academic Performance: Analysis through the social capital. University of Eastern Finland.

Kiplagat, P. and Mongina Ombiro, R. M. (2017). Social Media Usage and Academic Performance in Secondary Schools, Kenya. International Journal of Trend in Research and Development, Vol. 3(6), ISSN: 2394-9333, www.ijtrd.com. https://www.researchgate.net/publication/312981450.

Kirschner, P. A. and Karpinski, A. C. (2009). Facebook ${ }^{\circledR}$ and Academic Performance. Open University of the Netherlands, the Ohio State University.

Mingle, J. and Adams, M. (2015). "Social Media Network Participation and Academic Performance in Senior High Schools in Ghana". Library Philosophy and Practice (e-journal). University of Nebraska - Lincoln DigitalCommons@University of Nebraska - Lincoln. http://digitalcommons.unl.edu/libphilprac/1286.

Mingle, J., Adams, M. and Adjei, E. A. (2014). A Comparative Analysis of Social Media Usage and Academic Performance in Public and Private Senior High Schools. Journal of Education and Practice. www.iiste.org. Vol.7(7). ISSN 2222-1735 (Paper) ISSN 2222-288X (Online).

Muhingi, W. N, Mutavi, T. Kokonya, D. Simiyu, V. N. Musungu, B., Obondo, A. Kuria, M. W. (2015). Social Networks and Students' Performance in Secondary Schools: Lessons from an Open Learning Centre, Kenya. Journal of Education and Practice, www.iiste.org. Vol.6 (21); ISSN 2222-1735 (Paper) ISSN 2222-288X (Online)

Mwadime, E. M. (2015). An investigation on the impact of online social networking on academic performance among high school students in urban areas: A case study of Westland's sub-county, Nairobi. School of Journalism and Mass Communication, University of Nairobi.

Ogundijo, O. (2014). Use of Social Networking among Secondary School Students: Implications for Academic Performance. Scientific Research Journal (SCIRJ), Vol. II(V), pp. 17 - 34. ISSN 2201-2796. www.scirj.org.

Okundia, R. A. (2016). Social Media and Students Academic Performance. University Of Benin, Benin City.

Othman, W. R. W., Apandi, Z. F. M. and Ngah, N. H. (2017). Impact of Social Media Usage on Students' Academic Performance in Terengganu, Malaysia. Journal of Applied Environmental and Biological Sciences. TextRoad Publication; www.textroad.com. Vol. 7(5), pp. 140-144.

Pasek, J., More, E. and Hargittai, E. (2009). Facebook and academic performance: Reconciling a media sensation with data. Vol. 14 (5 - 4), pp. 1-15. http://firstmonday.org/ojs/index.php/fm/rt/printerFriendly/2498/2181.

Peiro' -Velert C, Valencia-Peris A, Gonza'lez LM, Garci'a-Masso' X, Serra-Año' P, et al. (2014) Screen Media Usage, Sleep Time and Academic Performance in Adolescents: Clustering a Self-Organizing Maps Analysis. PLoS ONE 9(6): www.plosone.org. e99478. doi:10.1371/journal.pone.0099478.

Peter, O. (2015). Social media and academic performance of students in University of Lagos. University of Lagos.

Rithika M. and Selvaraj, S. (2013). Impact of Social Media on Student's Academic Performance. International Journal of Logistics \& Supply Chain Management Perspectives (C Pezzottaite Journals. Vol. 2(4), pp. 63440, ISSN (P):2319-9032, (O):2319-9040.

Vigie, A.and Nala, Z. (2015). New Media Consumption and Effects on the Academic Performance of Scholars. Philippine Association of Communication Educators Foundation Incorporated.

Cohen, L., Manion, L., and Morrison, K. 2007. Research Methods in Education (6th ed.). New York, USA: Routledge.

Kothari, C. R. 2004. Research methodology: Methods and techniques. New Age International.

Creswell, J. W. 2014. Qualitative, Quantitative and Mixed Method Approach to research Design. Fourth edition. Sage Publication.

Kumar, R. 2011. Research methodology. A step-by-step guide for Beginners, Sage Publication Ltd. Olivers Yard 55 city Road, ECIX ISP

Yamane, T (1967). Statistics, An Introductory Analysis, 2nd Ed., New York: Harper and Row 